University of Chicago Law School

Chicago Unbound

Public Law and Legal Theory Working Papers

Working Papers

2011

\title{
Talk about Talking about Constitutional Law
}

Adam M. Samaha

Follow this and additional works at: https://chicagounbound.uchicago.edu/public_law_and_legal_theory

Part of the Law Commons

Chicago Unbound includes both works in progress and final versions of articles. Please be aware that a more recent version of this article may be available on Chicago Unbound, SSRN or elsewhere.

\section{Recommended Citation}

Adam Samaha, "Talk about Talking about Constitutional Law" (University of Chicago Public Law \& Legal Theory Working Paper No. 368, 2011).

This Working Paper is brought to you for free and open access by the Working Papers at Chicago Unbound. It has been accepted for inclusion in Public Law and Legal Theory Working Papers by an authorized administrator of Chicago Unbound. For more information, please contact unbound@law.uchicago.edu. 


\section{CHICAGO}

Public LaW and Legal Theory Working Paper No. 368

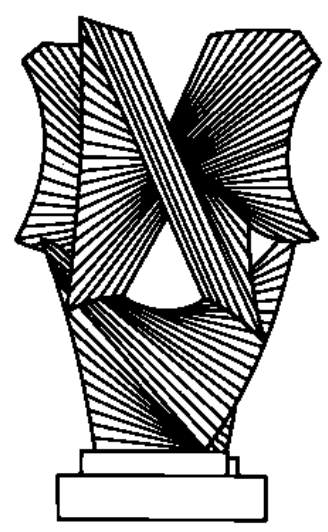

TALK ABOUT TALKING ABOUT CONSTITUTIONAL LAW

Adam M. Samaha

\section{THE LAW SCHOOL THE UNIVERSITY OF CHICAGO}

October 2011

This paper can be downloaded without charge at the Public Law and Legal Theory Working Paper Series: http://www.law.uchicago.edu/academics/publiclaw/index.html and The Social Science Research Network Electronic Paper Collection. 


\title{
TALK ABOUT TALKING ABOUT CONSTITUTIONAL LAW
}

\begin{abstract}
Adam M. Samaha*
Constitutional theory branches into decision theory and discourse theory. The former concentrates on how constitutional decisions are or should be made, the latter on how constitutional issues are or should be discussed. For its part, originalism began as a method for resolving constitutional disagreement but it has migrated into discourse theory, as well. Jack Balkin's "living originalism" illustrates the move. This essay examines inclusive versions of originalism like Balkin's that permit many different answers to constitutional questions. The essay then suggests pathologies associated with loose constitutional discourse in general. For instance, a large domain for constitutional discourse can crowd out nonconstitutional argument and raise the stakes of disputes in ways that discourage compromise, creativity, and trust. Under certain conditions, loose constitutional discourse is a distraction that cannot moderate societal divisions. At its worst, loose constitutional discourse retards progress toward goals that it is supposed to achieve. We still have much to learn about how constitutional discourse operates in fact and how it interacts with nonconstitutional argument. At the moment, those inquiries probably are more important than more talk about how we ought to talk about constitutional law.
\end{abstract}

Some people talk, some people decide. Other people talk about deciding, and still other people talk about talking. Of course talking and deciding are interrelated, ${ }^{1}$ but people tend to have a first love in these matters. This is true in my line of work. Although the title of "professor" designates us as talkers more than deciders (to the relief of countless citizens), there is plenty of diversity in what we discuss. For example, much scholarly effort has been devoted to constitutional decisions, including empirical studies of judicial behavior, recommendations on interpretive method, and consideration of institutional choice and design. Significant work also has been done on constitutional discourse, including studies of rhetoric in popular culture and in social movements, as well as proposals for conducting rational or otherwise constructive deliberation on constitutional questions.

\footnotetext{
* Professor of Law, The University of Chicago Law School. This essay was drafted for a symposium on Jack Balkin's Living Originalism (2011), hosted by the University of Illinois Law School on April 8 and 9, 2011. I thank the symposium participants, and especially Jack Balkin, for their reactions to an earlier draft. I also received helpful feedback from Barry Friedman and Lior Strahilevitz. Mistakes are mine.

${ }^{1}$ Talking involves a kind of decision, talking can constitute a decision, talking can facilitate other decisions, decisions can facilitate talking, and some decisions are not much more than talk. Precisely separating the two phenomena is not easy. I hope that undefined categories based on intuition are adequate.
} 
To the extent that it remains one single thing, originalism now has a role in both decision theory and discourse theory. The former role is more familiar. We are accustomed to enthusiasts promoting originalism as a method of deciding constitutional questions, especially for judges. It can be used by other decision-makers, to be sure, but sound constitutional decisions had been the focus of originalist thinking, regardless. In contrast, some recent theoretical work on originalism departs from this tradition. Some theorists do not present their ideas about originalism as comprehensive advice for making decisions in identifiable cases. Instead they pursue originalism as a way to ascertain law's meaning in an isolated sense and without necessarily recommending much of anything in terms of case results, ${ }^{2}$ or as a way to discuss constitutional values regardless of institutional location and without necessarily taking positions on today's contested issues. Theories of this kind are not well-designed to answer direct questions such as, "Is there a judicially enforceable federal constitutional right to same-sex marriage?”

If developed further in this direction, originalism might self-destruct or, putting the thought more cautiously, the new versions of originalism might confirm an old criticism. A long-standing objection has been that, for one reason or another, the historical sources on which originalism relies cannot really dictate answers to interesting questions that people have about constitutional law in the United States today. ${ }^{3}$ A darker suspicion sometimes follows: If one believes that originalism is plagued by indeterminacy, then one might conclude that people who use originalism to advocate particular constitutional positions are driven by the same kind of political commitments that they often claim to exclude from their analysis. What could have been a simple concern about whether originalism generates answers can turn into a conviction that originalists are deluded, hypocritical, or deceptive.

But this is no criticism of an originalism that has nothing to do with decisions. The above complaints are based on an alleged disconnect between originalism and some pattern of results - the indeterminacy complaint alleges that that there can be no pattern; the deception complaint alleges that there is a pattern dictated by politics. But if originalism, rightly understood, can only ascertain what "equal protection" means in a literary sense without telling judges what to do with that meaning, or if it can only facilitate a

\footnotetext{
2 See, e.g., Gary Lawson, On Reading Recipes . . . and Constitutions, 85 GEO. L.J. 1823, 1823-24 (1997) (segregating the concept of interpretation from the practice of adjudication); Lawrence B. Solum, Semantic Originalism 27-30 (2008) (unpublished manuscript), available at http://ssrn.com/abstract=1120244. These theories of interpretation do not fit easily into the category of discourse theory, but neither do they fit easily into the category of decision theory. Some theories of interpretation have an abstract quality shared with some discourse theories, and this is the connection that I am making in the text.

${ }^{3}$ See, e.g., Paul Brest, The Misconceived Quest for the Original Understanding, 60 B.U.L. REV. 204, 218-22 (1980).
} 
discussion about what "equal protection" should mean today, then many opponents of originalism can calm down. There would be no superimposed pattern of results in specific controversies to fuel the deception charge. And the now-conceded indeterminacy of originalism might even have beneficial consequences. Originalism might become anyone's tool. Methodological détente might come into view. Constitutional debate might become more civil and disagreement more manageable.

Or perhaps the shift in focus will be a loss of focus, with divisions remaining equally wide and the task of decision equally urgent. In this essay, I develop this skeptical attitude toward discourse theory and the new originalism. I will not show that discourse theorizing is necessarily wasteful, but I will offer uncomfortably mixed views on recent talk about talking about constitutional law. ${ }^{4}$ My principal doubt involves whether a relatively loose constitutional discourse tends to increase the legitimacy of a political system. An inclusive discourse that allows for many possible answers to constitutional questions does sound friendly. But talk can accomplish only so much, and constitutional talk can raise the stakes of disputes in a way that discourages rather than encourages compromise, creativity, and trust. If a large domain for constitutional discourse crowds out nonconstitutional argument, participants in the political system may find themselves further divided, not united, by easy recourse to constitutional claims.

\section{More Constitution TALK}

Converting policy positions into constitutional arguments is a remarkable practice in the United States. "Constitutional" can mean several things but here I refer to supreme law, as in a trumping norm that cannot be beaten within the rules of legal argument. Having supreme law on your side is the power to overcome all other claims sourced in law. If people believe that they should abide by the law, it is also the power to make disagreement with you a source of shame or ethical crisis. Acting against your position must take the form of extralegal resistance, which is only occasionally valorized and more often a sign of danger to ordinary people. This helps explain why even the radical fringes of a society might engage in constitutional argument before invoking so-called higher law, let alone the virtues of law-breaking. Thus socialist Charles Schenck's leaflet relied on the Thirteenth Amendment as a reason to resist military conscription during World War I, ${ }^{5}$ and the Black

\footnotetext{
${ }^{4}$ Part of my discomfort stems from my decision to talk about talk about talking about constitutional law, but this is not the only source of my mixed feelings.

5 "The Constitution of the United States is one of the greatest bulwarks of political liberty. ... - A conscripted citizen is forced to surrender his right as a citizen and become a subject. He is forced into involuntary servitude. He is deprived of the protection given him by the Constitution of the United States.” Transcript of Record at 4 (insert), Schenck v. United States, 249 U.S. 47 (1919) (No. 437).
} 
Panther Party's second platform relied on the Second Amendment as a reason for black people to arm themselves in the face of police brutality. ${ }^{6}$

Because this practice is so long-standing, deployed in the service of so many ideologies, and used in so many argument settings, investigating constitutional discourse as a generalized whole might be worthwhile. ${ }^{7}$ Interested scholars could carefully identify features of this practice that occur regardless of context but that distinguish it from nonconstitutional discourse. From there, we might better understand a significant part of our politics. Constitution talk probably does structure people's thinking to some extent. Mapping this form of discourse should help reveal how political participants communicate with each other, how their opinions are influenced by constitutional debate, and when the influence of such talk runs out. Various contributions have been made along these lines during the last thirty years and more. The notion of a deliberative democracy once attracted excitement, ${ }^{8}$ a participatory democratic model vied for attention, ${ }^{9}$ and the cool kids in constitutional theory moved outside the courtroom to study the external origins of acceptable constitutional arguments. ${ }^{10}$ To the extent that institution-specific analysis in legal theory ${ }^{11}$ underemphasizes such crossinstitution phenomena, discourse theory might be a welcome corrective.

Jack Balkin's recent writings are illustrative. They draw from traditions in constitutional debate beyond the judiciary, and they recommend ground rules for the future. ${ }^{12}$ Balkin wants participants to fit their arguments with the text of the Constitution of the United States, plus general principles that can be associated with that document. But otherwise, all bets are off. Discarding

\footnotetext{
6 "We believe we can end police brutality in our black community by organizing black selfdefense groups that are dedicated to defending our black community from racist police oppression and brutality. The Second Amendment to the Constitution of the United States gives a right to bear arms. We therefore believe that all black people should arm themselves for self defense.” BLACK PANTHER PARTy Platform AND PROGRAm 97 (Oct. 1966).

${ }^{7}$ I do not mean that constitutional arguments are more common than other forms of argument in the United States; it seems clear to me that the opposite is true.

${ }^{8}$ See, e.g., Amy Gutmann \& Dennis F. Thompson, Democracy and Disagreement (1996).

${ }^{9}$ See, e.g., Benjamin R. Barber, Strong Democracy: Participatory Politics for a New AGE (1984).

${ }^{10}$ See, e.g., Larry D. Kramer, The People Themselves: Popular Constitutionalism And Judicial ReVIEW (2004); Barry Friedman, Mediated Popular Constitutionalism, 101 Mich. L. ReV. 2596, 2602 (2003); Reva B. Siegel, Text in Contest: Gender and the Constitution from a Social Movement Perspective, 150 U. PA. L. REV. 297 (2001).

${ }^{11}$ See, e.g., Neil K. Komesar, Imperfect Alternatives: ChoOsing Institutions in LAW, Economics, AND Public Policy (1994); Cass R. Sunstein \& Adrian Vermeule, Interpretation and Institutions, 101 Mich. L. REV. 885 (2003).

12 See JACK BALKIn, Living Originalism (2011); see also JACK BALKin, Constitutional REDEMPTION: Political FAITH In AN UnJUST WORLD (2011).
} 
the jargon and shrinking an effusive argument into a few words, his recommendation is basically this: Divide the document into rules and standards, follow the rules, and leave the standards vague. ${ }^{13}$ The Constitution means no less and no more, although it turns out that we all have a lot of "constitutional construction" to do after the document's meaning runs out. Vague constitutional standards are Balkin's special concern, and he emphasizes that we can be faithful to the original meaning of certain parts of the Constitution only by refusing to replace these standards with the specific expected applications of past generations. What those generations expected to happen after enactment is not necessarily what the vague parts of the enacted text mean, for us or for them. ${ }^{14}$

Importantly, however, the original meaning of the Constitution is not the outer boundary of constitutional argument. True, Balkin contends that treating the Constitution as law requires fidelity to the document's original semantic meaning, which is sometimes a vague standard instead of a specific lesson. In those situations, claiming that the Constitution means something specific would be disregarding the document, not following it. But Balkin also knows that abstract standards will not provide clear answers to many contemporary disputes, and he wants constitutional discourse to deliver at least some of these answers. This is where "constitutional construction" comes into play. ${ }^{15}$

What is constitutional construction, exactly? Theorists sympathetic to the idea are still toying with various specifications, and there is no consensus on which institutions ought to be engaged in the practice. ${ }^{16}$ For Balkin,

${ }^{13}$ He also stresses "principles" but the difference between standards and principles is not terribly dramatic. Balkin's principles are values that must be considered but that are vague in their boundaries and in how they apply to particular circumstances. See BAlKin, Living Originalism, supra note 12, at _ (manuscript at 314-17 n. 12) (discussing rules, standards, and principles).

${ }^{14}$ See, e.g., id. at _ (manuscript at 105-08). Balkin's distinction between original meaning and original expected application is not new. Ronald Dworkin trumpeted roughly the same divide in the 1980s, distinguishing concepts from conceptions. See RONALD DWORKIN, LAW's EMPIRE 7172 (1986) (relating the distinction to levels of abstraction and the exposure of disagreement); see also RONALD DWORKIN, JUSTICE IN ROBES 120-23 (2006) (distinguishing abstract moral principles that he finds in certain constitutional provisions from the expected applications of those provisions). The level-of-generality issue has been around for a long time, too. See, e.g., Laurence H. Tribe \& Michael C. Dorf, Levels of Generality in the Definition of Rights, 57 U. CHI. L. REV. 1057, 1061-63 (1990) (covering both enumerated and unenumerated rights); Paul Brest, The Fundamental Rights Controversy: The Essential Contradictions of Normative Constitutional Scholarship, 90 YALE L.J. 1063, 1091-92 (1981) (“[A]ll adjudication requires making choices among the levels of generality on which to articulate principles ....”).

${ }^{15}$ See BALKIn, Living Originalism, supra note 12, at _ (manuscript at 103) (distinguishing “interpretation-as-construction” from “interpretation-as-ascertainment”).

${ }^{16}$ See, e.g., Randy E. Barnett, Restoring the Lost Constitution: The Presumption of LIBERTY 118-23 (2004) (characterizing constitutional construction as principled gap filling to resolve cases after interpretation runs out, and indicating substantial judicial involvement); Keith E. 
construction is composed of today's conventional modes of constitutional argument and the results reached thereunder, minus the Constitution's original semantic meaning. Thus the entire range of arguments that lawyers, judges, and various advocates now use to make constitutional claims would remain available under his model. You could still rely on Supreme Court precedent; I could still rely on drafting history; we both could attempt to change the culture, the politicians, and the judges who decide constitutional questions. It is just that many of those efforts would be categorized as attempts merely to implement the Constitution's original meaning at a given point in time, instead of establishing the Constitution's original meaning for all time. So, absent formal amendment, the original meaning of the Constitution would remain stable - but the contemporary construction of grand phrases such as "equal protection of the laws" and grand concepts such as "separation of powers" could be contested during each generation and, at some point, repudiated. In this way, Balkin synthesizes one version of originalism with one version of living constitutionalism. ${ }^{17}$

Although mixing sources for constitutional argument is commonplace, not everyone practices constitutional debate in Balkin's way and so his effort has a live normative element. Some originalists might prefer to specify the meaning of vague clauses in accord with concrete historical examples, or at least follow the level of generality suggested by that history. Balkin opposes these positions. Some nonoriginalists might prefer to treat judicial precedent on par with any other source of supreme law, or at least give these decisions a strong presumption of correctness. Balkin opposes these positions, too. He wants to leave major constitutional questions underdetermined by constitutional meaning as a strategy for increasing the legitimacy of the system. $^{18}$ Supposedly, people will debate and disagree over constitutional

Whittington, Constructing a New American Constitution, 27 Const. Comment. 119, 120-29 (2010) (placing constitutional construction on a continuum between interpretation and change, and emphasizing nonjudicial action); Lawrence B. Solum, The Interpretation-Construction Distinction, 27 CONST. COMmENT. 95, 100-08 (2010) (discussing interpretation as the process of ascertaining linguistic meaning and construction as involving the legal effect of legal texts, without plainly preferring judicial over nonjudicial involvement in the latter); $c f$. RICHARD H. FALLON, JR., IMPLEMENTING THE CONSTITUTION (2001) (concentrating on judicial doctrine as a mechanism for implementing constitutional norms). A critique of the emerging interpretation/construction distinction that separates original semantic meaning from legal meaning is Mitchell N. Berman, Constitutional Constructions and Constitutional Decision Rules: Thoughts on the Carving of Implementation Space, 27 Const. CommenT. 39 (2010). For a pragmatic view that integrates the meaning of a constitutional provision with its implementation, see Roderick M. Hills, Jr., The Pragmatist's View of Constitutional Implementation and Constitutional Meaning, 119 HARV. L. REV. F. 173, 175 (2006).

${ }^{17}$ Accord Solum, supra note 16, at 117 (observing that living constitutionalism might live within "the construction zone" that is demarcated by original semantic meaning).

${ }^{18}$ See BALKIn, Living ORIginalism, supra note 12, at _ (manuscript at 402-20) (relying on several versions of legitimacy). 
norms without permanently splitting into camps of Red and Blue, camps that aim to establish sole proprietary rights to the Real Constitution. If we use the Constitution as a common language or source of authority that is not too restrictive, the argument runs, we might bridge several societal divisions: cultural divisions over values, status divisions between commoners and legal professionals, and intergenerational divisions between our judgment and ancient judgments. Each generation will fight over fundamental questions, but all sides may point to the Constitution at any time, and the losing side might have "faith" that the prevailing regime will be "redeemed" in due time.

\section{TALK SKEPTICISM}

A legitimating constitutional discourse might be a friendly compromise for a political community that should be held together, but proposals to achieve it arrive with complications. These complications arise even if we forget about the particular institutions in which constitutional decisions are made, and instead ponder how constitutional discourse might be formulated in more abstract terms. I raise three problems here. The first two involve pathologies that can arise from relatively loose versions of constitutional discourse, while the third applies to a conservative version of constitutional discourse that Balkin seems to endorse. ${ }^{19}$

\section{A. The Domain Problem}

Constitutional debate is not the only game in town. It might seem more significant, or more interesting, or more thrilling than other types of debate.

${ }^{19}$ I put aside three other problems related to the health of our politics.

First, one might think that the character of constitutional discourse will influence how constitutional text is drafted going forward and that this influence should be defended. I will assume that new text via Article $\mathrm{V}$ or constitutional convention is not likely to happen with sufficient frequency to make ex ante drafting incentives important (an assumption that seems safe under loose versions of constitutional discourse, anyway).

Second and more significant, the character of constitutional discourse can have an effect on the formal amendment rate and, once again, one might fairly demand that any such effect be defended. A convincing defense would require a thorough comparison of Article $\mathrm{V}$ with other lawmaking procedures, which is not obviously the kind of analysis that excites discourse theorists. Cf. Adrian Vermeule, Constitutional Amendments and the Constitutional Common Law, in THE Least Examined Branch: The Role of Legislatures in the Constitutional State 229 (Richard W. Bauman \& Tsvi Kahana eds. 2006) (comparing judicial updating to formal amendment).

Third, one might think that most of the debatable constitutional questions are not very important to society's well-being. Balkin's version of constitutional discourse might well leave the most important features of the constitutional order untouched, such as the specific rules regarding the composition of Congress, while directing excessive attention to a few vague clauses and principles. See SANFORD LEVINSON, OUR Undemocratic Constitution (2006). I will charitably assume that enforcement decisions regarding vague standards in the U.S. Constitution are socially significant, or that debate over those standards can have legitimating effects regardless of the social consequences following their enforcement. 
Sometimes it is. But people constantly communicate with each other in nonconstitutional registers, even when debating issues that are intensely important to them. Constitutional argument is, in fact, an outlier practice for normal human beings. Even for law professors, actually. We direct large amounts of analytic effort to policy questions without consciously or subconsciously developing constitutional positions. Whether inside or outside the academy, then, you can discuss the appropriate amount of carbon dioxide emissions as a personal ethical matter without making a broader moral claim; you can make a moral claim about human emissions without making a legal claim; you can make a legal claim about those emissions without making a constitutional claim; and, if you like the dichotomy between interpretation and construction, you can make a claim about how the Constitution should be constructed today to deal with emissions without making a claim about what the Constitution means forevermore. ${ }^{20}$

A major challenge for normative discourse theorists is identifying the correct domain for constitutional argument in relation to nonconstitutional argument. These two types of discourse should be considered together because, although they are distinguishable practices, the rules for one are likely to affect the shape of the other. The challenge is probably more complicated if we have to make an interpretation/construction dichotomy. In that case, discourse theorists must defend some particular mix of (1) argument over constitutional meaning, (2) argument over constitutional construction, and (3) argument over nonconstitutional policy. Can discourse theorists persuasively show which proportions of argument types are best? Can they explain the interrelationships between these types? Have they tried? As far as I know, the answer to these questions is "no."

Constitutional discourse does seem meaningfully different from other kinds of discourse, at least insofar as a constitutional argument involves resort to norms that are confined to law but that have no superior within law. That said, figuring out how much constitutional argument is ideal for a political community of any significant scale is an extraordinarily difficult task. Even the more modest question whether we ought to have a bit more or a bit less constitutional argument is tricky. Large difficulties would persist even if we all agreed on the goal for setting the domain, such as maximizing legitimacy specified in some way. Overcoming these difficulties demands a reliable model of human psychology and behavior. The model must be sophisticated

\footnotetext{
${ }^{20}$ I do not want to claim that these categories are easy to delineate or that they do not overlap, whether in terms of how people think about their arguments or how they express them. In private correspondence with me, Barry Friedman was right to warn about the difficulties involved in identifying different types of normative argument, at least as a functional matter. Nevertheless, the content of these arguments do differ, as I indicate below. They are meaningfully distinct genres, and they tend to be treated that way by discourse theorists.
} 
enough to compare the effects of differing amounts and even types of constitutional claims on achieving the given goal. My sense is that no one has presented much more than speculation on these matters. ${ }^{21}$

At the same time, different versions of proper constitutional discourse will have different effects on the overall amount of constitutional argument. Take Balkin's version, which strives to leave open many fundamental questions for constitutional construction. He sees value in avoiding too much constitutional settlement. A predictable consequence, however, would be more constitutional debate than many other alternative versions of constitutional discourse. Balkin attempts to defend a spacious zone for constitutional construction in relation to constitutional meaning, but he does not offer any thoughts about the domain of constitutional argument in relation to nonconstitutional argument. He is working on one margin but his position implicates more than one. In fact, at least three dimensions of discourse are in play. By adopting the interpretation/construction distinction, theorists such as Balkin beg inquiry into the interactions among two forms of constitutional argument as well as nonconstitutional argument (which itself is separable into thinner slices). Claims regarding constitutional construction might gobble up any number of significant policy disagreements no matter how small we make the space for constitutional meaning. The looser the discourse on constitutional construction becomes, the larger the resulting domain relative to nonconstitutional discourse, all else equal. Is that a desirable direction in which to move? Is it better than leaving everything that Balkin calls constitutional construction to so-called ordinary politics? How can we tell?

Suppose the goal is widespread acceptance of the political and legal order. Perhaps this is not the highest end for human institutions, but it is an understandable concern of constitutional theory. ${ }^{22}$ I would not quickly concede that discourse or debate necessarily promotes acceptance rather than hardening positions and increasing alienation. Under some circumstances and at some point, silence or separation helps settle things. But suppose

\footnotetext{
${ }^{21}$ No doubt there is a floor on the domain of constitutional argument; someone will cast a claim in constitutional terms so long as the category exists and so long as compliance with law retains respectability. But recognizing the hardiness of constitutional assertions does little or nothing to justify some particular size or shape for the domain of such claims.

${ }^{22}$ To be clear, simple psychological acceptance and sociological legitimacy are not Balkin's only concern. See BALKIN, Living ORIGINALISM, supra note 12, at _ (manuscript at 408-09) (distinguishing sociological, legal, and moral legitimacy). But those are relevant issues for him, see, e.g., id.; id. at _ (manuscript at 1360) ("Constitutional constructions become durable when people stop fighting about them and accept them in practice.”), and many others, see, e.g., Richard H. Fallon Jr., Legitimacy and the Constitution, 118 HARV. L. REV. 1787, 1795-96 (2005); id. at 1805 ("The Constitution is law not because it was lawfully ratified, as it may not have been, but because it is accepted as authoritative.”); Adam M. Samaha, Dead Hand Arguments and Constitutional Interpretation, 108 ColuM. L. REV. 606, 625 (2008).
} 
otherwise. Suppose that human beings invariably respect each other more and accept defeat more gracefully after a good long talk. This conclusion would stretch the evidence on sociological and psychological legitimacy, ${ }^{23}$ but let us be generous. We still must know the effect of constitutional talk before we can begin to evaluate various models for constitutional discourse.

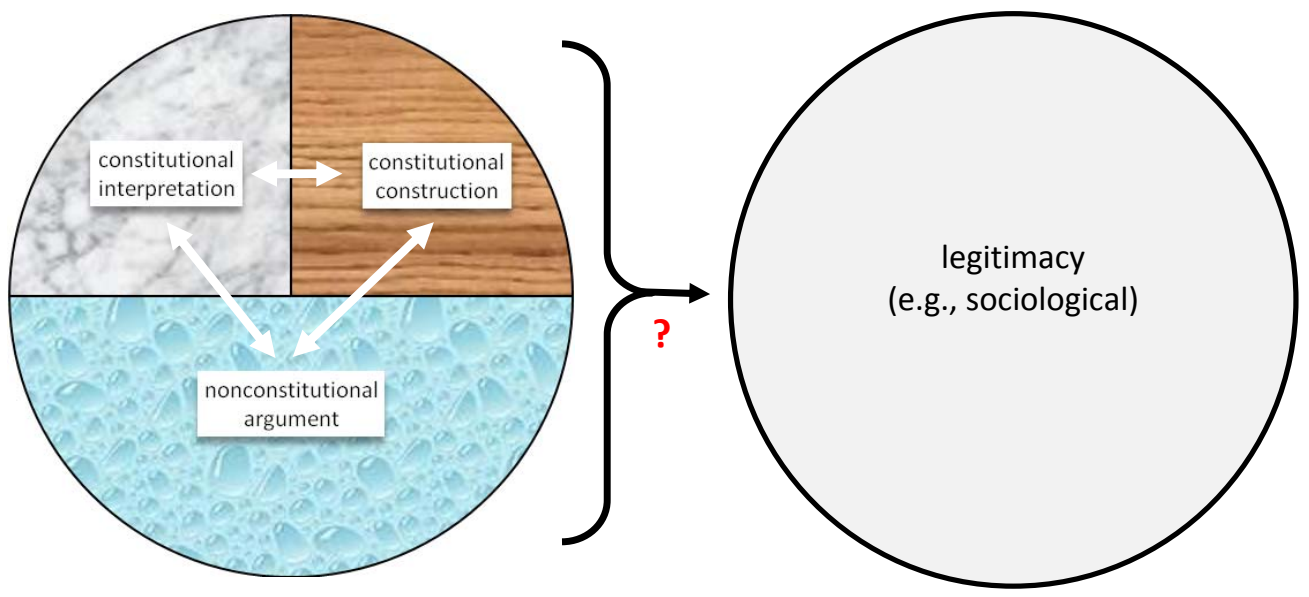

We should ask whether the temperature of social conflict goes up or down when arguments are easy rather than difficult to convert into constitutional terms. One hypothesis is that more people will more easily buy into the system if they all have easy access to constitutional claims, which they may hope will prevail within a generation or two. ${ }^{24}$ But there is no reason to leave that suggestion untested. A plausible competing hypothesis is that few people truly care much about events that will occur generations after their death, let alone merely possible events. Although people regularly talk about their care for future generations ("our children's children" and all that), it is difficult to find reliable evidence of personal sacrifice that is best explained by the desire to benefit the future. ${ }^{25}$ For the political left, an illustration might be

\footnotetext{
${ }^{23}$ Cf. David L. Markell, Tom Tyler \& Sarah F. Brosnan, What has Love Got to Do with It?: Sentimental Attachments and Legal Decision-Making 5-6, 15-23 (Sept. 7, 2011) (concluding from a web-based survey of a non-random sample of "elites" $(n=228)$ interested in land-use disputes that, (1) for protecting monetary values, positive responses were associated with the perceived neutrality of the judge, and (2) for protecting sentimental values, positive responses were associated with trust in the judge, which partly turned on opportunities for voice and signs of respect), available at http://ssrn.com/abstract=1923807. The survey also indicated that court judgments garnered the highest overall level of acceptance among five dispute-resolution procedures tested, but that courts placed third behind referenda and negotiation in protecting sentimental value. See id. at 18 .

${ }^{24}$ See BALKIN, Living ORIGinAlism, supra note 12, at _ (manuscript at 402-20).

${ }^{25}$ Among the empirical contributions on this topic, consider, for instance, Arthur C. Brooks, Do People Really Care About the Arts for Future Generations?, 28 J. Cultural ECON. 275, 283 (2004) (unable to reject the hypothesis that people are "purely intergenerationally egoistic" in their support for public art); Arthur C. Brooks, Public Goods and Posterity: An Empirical Test of
} 
convenient doubts about climate change that developed once economic recession made immediate sacrifice for long-term gain more burdensome. For the political right, an illustration might be the convenient belief that Keynesian stimulus programs were necessary to prevent recession from turning into depression, whatever the cost in future debt burdens.

Yet another competing hypothesis would be equally devastating. Perhaps constitutionalizing arguments makes the stakes of a given dispute appear higher than otherwise. ${ }^{26}$ And perhaps the perception of high stakes drives down the probability of compromise and trust. Although relevant empirical and experimental evidence is hardly consistent or conclusive, there is plenty of reason to believe that high-stakes questions often prompt people to fight harder and take fewer risks on innovative proposals for reconciliation. ${ }^{27}$ One can hope that people concentrate on the public good when the problems they face escalate in importance, and this no doubt happens under certain conditions, but discourse theories ought to rest on more than optimism. The easy conversion of policy positions into constitutional claims might make the urge to prevail over others ever stronger. Supreme law would be at stake, after all. If all of this is true, any causal link between loose constitutional discourse and a cohesive political community would disappear. The polarizing effects could easily outrun the cohesive effects.

True, in its most extreme version, loose constitutional discourse probably would not increase the stakes of argument. Indeed the loosest imaginable constitutional discourse could eliminate the stakes entirely by eroding any difference with ordinary political argument. If every policy position could

Intergenerational Altruism, 13 J. PuB. ADMIN. Res. 165, 173-74 (2003) (testing whether reported charitable giving to social services, education, religion, and politics have an intergenerationally altruistic component and answering “yes," but only narrowly and only for the last two); David Popp, Altruism and the Demand for Environmental Quality, 77 L. ECON. 339, 348 (2001) (finding some evidence that people value environmental amenities both for themselves and for future generations).

${ }^{26}$ Contrast prospective gains and losses, however. See, e.g., Daniel Kahneman \& Amos Tversky, Choices, Values, and Frames, 39 Am. Psychologist 341, 344 (1984) (finding that people are risk-seeking when facing losses and risk-averse when facing gains); Jeffrey J. Rachlinski, Gains, Losses, and the Psychology of Litigation, 70 S. CAL. L. REV. 113, 118-19 (1996) (similar); Chris Guthrie, Framing Frivolous Litigation: A Psychological Theory, 67 U. CHI. L. REV. 163, 167 (2000) (stating that the reverse is true for low probability losses and gains).

${ }^{27}$ See, e.g., Olof Johansson-Stenman, Minhaj Mahmud \& Peter Martinsson, Does Stake Size Matter in Trust Games?, 88 EcON. LeTTERs 365, 367-68 \& tbls. 1 \& 2 (2005); Charles A. Holt \& Susan K. Laury, Risk Aversion and Incentive Effects, 92 AM. ECON. REV. 1644, 1647, 1653-54 (2002); George L. Priest \& Benjamin Klein, The Selection of Disputes for Litigation, 6 J. LEGAL STUD. 1, 4-5, 17 (1984); see generally Adam M. Samaha, Low Stakes and Constitutional Interpretation, 13 U. PA. J. CoNST. L. 305, 322-26 (2010) (reviewing theory and research on lowstakes versus high-stakes decision making); cf. MARY AnN Glendon, Rights TAlK: The IMPOVERISHMENT OF POLITICAL DisCOURSE at x (1991) (decrying the "exaggerated absoluteness, . . . hyperindividualism, ... [and] insularity” of rights talk in the United States). 
easily be recast as a viable constitutional argument at any point in time, it is unclear what would be gained from the label. An argument could not aspire to greater durability on account of its constitutional status, for instance; no one could win a constitutional argument for any measurable length of time. Characterizing your argument as constitutional might only signal strong feelings, or do nothing at all. However, neither Balkin nor others working on discourse theory seems to water down the significance of winning a constitutional argument that much. Balkin's suggestion appears to be that prevailing constitutional constructions should be less difficult to change than the Constitution's original meaning yet more difficult to change than nonconstitutional policy. This difference between construction and policy is not immediately apparent in Balkin's book; his subject is constitutional discourse, not nonconstitutional discourse. But this is the problem.

Finally, relatively loose standards for constitutional discourse might have other alienating and aggravating effects. Surely some advocates will use constitutional arguments strategically, knowing that some others will take their points more seriously in that form. As well, in attempting to prevent undesirable outcomes entailed by the constitutional arguments of others, objections that would have been cast in ordinary policy terms will more likely be translated into the language of constitutional law. Strategic and defensive uses of constitutional dialogue are not without social benefit; they generate useful information, for instance. Nonetheless, they seem to include a kind of cost to which discourse theorists should be sensitive. These practices involve opportunism and the embrace of arguments that do not reflect the honest feelings of their proponents. In a significant sense, they are inauthentic. It is worth wondering whether a loose constitutional discourse that is inflated by strategic uses can produce a more cohesive political community, to say nothing of a community whose cohesion is morally justified. ${ }^{28}$ Ordinarily, language is not the kind of common resource that can be overused. But the kind of language envisioned by constitutional discourse theorists might well be too attractive for the social good.

Nationalists and patriots, if no others, might be tempted to cite the United States as evidence that loose constitutional discourse works. This country has not split apart despite significant diversity and fundamental disagreement not for more than a century, anyway. The Constitution is indeed a unifying icon, despite or because its details are not widely known. ${ }^{29}$ In addition,

${ }^{28}$ I have in mind a connection to John Rawls's idea of public reason derived from an overlapping consensus of comprehensive doctrines, see JOHn RAWLS, THE LAW OF PEOPLES 132-40 (1999); John RAWLs, Political Liberalism 136-37 (1996), which might not, in fact, be adequate to the task of achieving sociological legitimacy in a diverse society insofar as people feel alienated from the public reasons available to them.

${ }^{29}$ See Michael Kammen, A Machine that Would Go of ItSelf 3 (1986) (“[F]or almost two 
theorists such as Balkin are not asking for constitutional debate to change in a radical way. And, compared to some originalists, Balkin might be allotting far more territory to constitutional construction than to the even higher stakes domain of constitutional meaning. On the other hand, only those who are satisfied with today's levels of political friction and polarization will take the United States as a success story on legitimacy. Cautionary tale might be the more fitting description. An unresolved question, moreover, is how best to maximize particular values such as political legitimacy with the least social dysfunction possible. Normative discourse theorists who accept the status quo are not demonstrating that we cannot do better. To do that, they will have to show that the character of constitutional debate cannot be changed by design, that such change would be too costly, or that change is unneeded because we happen to have the optimal mix of constitutional and nonconstitutional debate. Good work remains undone on each point.

\section{B. The Variance Problem}

A second problem has the same source as the domain problem. A loose constitutional discourse will not only attract a large number of policy arguments, it will encompass many conflicting viewpoints as well. Indeed, a socially important mission for normative discourse theory is building forums in which people with different views may understand and peacefully converse with each other. Therefore, the common "language" must be quite thin. It must not commit any of the (desired) participants to any of the contested positions that they happen to hold. As the variance in opinion that must be accommodated becomes higher, the rules of discourse must become thinner. To the extant that an inclusive model of constitutional discourse is advocated as a constructive response to ideological diversity, the model cannot be very confining in terms of acceptable constitutional positions.

At the same time, there will be losers. Many of them. Decisions will be made that privilege one constitutional position over another, at least in the short run. Hence the decision to forgo health insurance will be sheltered from legislative prohibition, or instead subject to legislative policy choices, or even abolished to support a constitutional right to health care. The decision to terminate a pregnancy will be sheltered from legislative prohibition, or instead subject to legislative policy choices, or even criminalized as a matter of constitutional law to avoid underinclusive murder statutes. These are only some conceivable constitutional positions that would be accommodated within a loose discourse. They cannot all prevail at the same time. Someone will lose (even if discourse theorists do not specify how the constitutional

centuries, [the Constitution] has been swathed in . . . a fulsome rhetoric of reverence more than offset by the reality of ignorance.”); Max Lerner, Constitution and Court as Symbols, 46 YALE L.J. 1290, 1294, 1298 (1937) (noting the role of symbol in fostering order). 
decision will be made).

Now we have a hitch in the peacemaking function of loose constitutional discourse. None of the losers can be convinced that they ought to accept their losses just because they accept the Constitution. Constitutional law, however supreme, would have no such persuasive force. The open dialogue was designed to avoid precisely this power. To be sure, there are reasons to doubt that many people stop fighting for their positions when other people tell them that the Constitution is against them. I am sympathetic to those doubts. But any such pacifying effect seems to be sacrificed by loose constitutional dialogue. We are left to wonder what legitimating value losers will assign to the message not that they were wrong about the true meaning of the Constitution, but rather that participants in the debate all began with the same indeterminate resources for legal argument. What difference can that make? Will it make acquiescence more likely or more justified because the result was not predetermined or not predictable?

Lotteries sometimes garner support on these grounds, ${ }^{30}$ but law covers both more and less of the territory in which randomized social decisions are defensible. Although it might be a calming sign of respect when political opponents use the same constitutional language, this is not always true. Boxers mimic handshakes at the beginning of their bouts without eliminating an ensuing brutality. Even if we think that tagging shared cultural elements has a unifying effect, it is not obvious why the effect would be greater or different than saluting the flag or tipping hats before the debate begins. Perhaps constitutional lingo is a fairly elaborate way of sending those signals, which could be jettisoned for purposes of simplification. Personally, I am not confident of this view but neither can I find obvious evidence on the other side. Serious discourse theorists should grapple harder with the mechanisms of legitimacy before concluding that the ability to formulate a vast spectrum of arguments in originalist terms will make any difference. ${ }^{31}$

Pointing to roughly equal chances in the short run is not the only way to promote a loose constitutional discourse, however. Another way to win the allegiance of today's losers is by emphasizing the long run. ${ }^{32}$ Consider one of the asserted benefits of a large domain for constitutional construction: Provisional settlements that merely implement the original meaning of the

${ }^{30}$ See Adam M. Samaha, Randomization in Adjudication, 51 WM. \& MARY L. REV. 1, 18-21 (2009) (setting out justifications for randomization, including equal claims to an indivisible good).

${ }^{31}$ This variance problem becomes worse as the domain of constitutional argument becomes larger, but the problem exists as long as the domain has a significant reach.

${ }^{32}$ Both Balkin and Mike Seidman suggest this possibility. The latter developed his argument ten years ago in Louis Michael Seidman, Our Unsettled Constitution: A New Defense of CONSTITUTIONALISM AND JUDICIAL REVIEW 55 (2001). 
Constitution are supposed to be vulnerable over time. Once participants in constitutional debate understand that any constitutional construction can be reformed with sustained argument and political mobilization, that only a partial framework for politics and government is even arguably fixed, then losers might have hope of turning the tables. For similar reasons, winners might be more restrained within a system of loose constitutional dialogue. They cannot be sure of lasting victory. They might have to prepare for life on the outskirts of political power.

If this sounds like rotation in office under conditions of electoral competition, it should. ${ }^{33}$ Essentially the same arguments can be made that competitive elections with organized political parties can increase sociological legitimacy to sustainable levels. The resemblance ought to prompt us to ask again about the added value of loose constitutional discourse, especially insofar as it holds out the promise of change through the channels of politics. Constitutional constructions are, at least in part, the products of popular opinion, social movements, and interest groups acting with and through officeholders, policy agendas, and program design. One of the contributions of constitutional discourse theory is a reminder that ordinary politics and constitutional law are inseparable practices. The more these two practices are connected, however, the less special legitimizing force loose constitutional discourse can possibly have.

Elections, however, take place in much shorter increments. Constitutional dialogue is ordinarily not modeled to have any such immediate effect, as I indicated above. Recognizing that change in constitutional constructions generally takes much longer and much more effort than change in ordinary policy opens up challenging questions about the relationship between the pace of legal change and the level of system legitimacy. Is it more soothing to think that your loss is reversible in the next election cycle, or in the next generation? If the response is that constitutional victories are supposed to be more entrenched than other political victories, and so constitutional losers rightly can be asked to wait, then I think the losers' reply will be that a loose constitutional dialogue minimizes the difference between constitutional and ordinary political victories. A dialogue loose enough to encompass the positions of a diverse political community implies that many if not all significant political victories can be recharacterized as constitutional commitments - and vice versa. One side’s constitutional victory will be

33 See generally Jack Goldsmith \& Daryl Levinson, Law for States: International Law, Constitutional Law, Public Law, 122 HARv. L. Rev. 1791, 1835 (2009). On the possibly constructive role of courts in maintaining these systems, see, for example, Samuel Issacharoff, Constitutional Courts and Democratic Hedging, 99 GEO. L.J. 961 (2011), and Matthew C. Stephenson, “When the Devil Turns . . .": The Political Foundations of Independent Judicial Review, 32 J. LEGAL STUD. 59 (2003). 
another side's ordinary political victory, and possibly an illegitimate one at that. And so we might hope that people keep singing the national anthem or start sporting flag pins to show membership in the same political community, and avoid the trouble of translating their arguments into a constitutional language that risks encompassing too much and accomplishing too little.

\section{The Conservatism Problem}

Certain versions of constitutional dialogue are not nearly as inclusive as the above concerns suggest. The acceptable outcomes from constitutional dialogue can be limited to what seems normal, or mainstream, or nondisruptive. If what started as a big tent gets smaller, there is the possibility for greater guidance on particular constitutional questions. This might be counted as a gain. But any advantage from clarity comes with the disadvantage, once again, of losing the losers' allegiance to the system. This risk is quite difficult to eliminate. It will arise from those who object to the narrowed set of acceptable outcomes and also from those who more generally oppose a conservative version of constitutional dialogue. While loosening the dialogue might garner more signatories, making the dialogue more outcomedeterminative will multiply its opponents. ${ }^{34}$

Balkin's work, in the end, exemplifies this more conservative option. Each application of his text-plus-principle approach - to the privileges or immunities clause, to the equal protection clause, to the commerce clause is a defense of some part of the status quo. ${ }^{35}$ If you felt uneasy about the ability of conventional constitutional analysis to unleash the federal government against the Great Depression and Jim Crow, and also to condemn school segregation and abortion regulation, text-plus-principle is supposed to place those outcomes in respectable legal standing. If instead you were comfortable with any of the opposite outcomes, Balkin's analysis can only make you feel uncomfortable (or unmoved). His conclusions are not presented as reasonable possibilities. They are the product of extensive argument designed to convince the reader of one particular conclusion after another, so long as the reader takes this form of constitutional discourse as given.

But I doubt that anyone will, and Balkin is not asking for that sort of charity. His argument for his form of constitutional discourse rests on its ability to bring people into the fold. The argument is supposed to be a

\footnotetext{
34 This section might suggest that legitimacy-seeking discourse theorists have been unfairly placed in a dilemma, whereby constitutional dialogue is always either too loose or too restrictive. I accept that there might be a way to thread the needle, but I also believe it is worth presenting both sorts of concerns, along with the general question regarding the value of constitutional discourse compared to other forms of debate.

${ }^{35}$ See BALKIN, Living OriginAliSM, supra note 12, at _ (manuscript chs. 9-11).
} 
response to the risk that people will further divide, polarize, and smash into or spin away from each other. Today, however, there is no consensus that expansion of the regulatory and welfare state represented by the New Deal and the Great Society is constitutionally permissible. If the goal is to convince people that text-plus-principle dialogue is able to produce mutually exclusive constitutional outcomes, one would like to see the method used to produce unorthodox results. If the method is not capable of achieving this if it cannot be used to generate conflicting answers to significant constitutional questions but instead only offers the possibility of serious change over generations - then adherence becomes far more costly to millions of people making choices now.

In application as opposed to theory, Balkin's text-plus-principle might not be well-designed for generating serious indeterminacy and perhaps better suited to validating the status quo against reform campaigns with short time horizons. In that case, this roughly defined model for loose talk about the Constitution which seemed so ideologically inclusive will function as a conservative demand that advocates of change slow down. The restraints on constitutional discourse which seemed so modest will become quite serious. And the implications for today's constitutional decisions will become quite clear. Even if the Constitution's original meaning remains radically loose, constitutional construction can take back almost all of the slack. That new constitutional constructions are easier to achieve than success in the nearly dormant Article $\mathrm{V}$ amendment process will be little comfort to those Americans who believe that the existing system has abandoned the Real Constitution. To them, constitutional construction probably seems like the problem, not the solution.

\section{CONCLUSION}

Much of the foregoing has been critical. I would like to close on a note of humility. Dealing with fundamental disagreement is not easy. It is almost certainly a problem that must be managed rather than solved. The difficulties are so deep that many ideas on the matter are better than few, and therefore we can welcome the efforts of Balkin and other discourse theorists. At the same time, they are only part of a larger intellectual community interested in when and why people accept decisions with which they disagree. Prominent scholarship on legitimacy has yet to deliver a comprehensive answer on the particular conditions for acceptance. ${ }^{36}$ Specialists in human behavior are

\footnotetext{
36 See, e.g., Tom R. Tyler, Why People Obey the Law 4-7, 161-63 (2006 ed.); Tom R. Tyler, Psychological Perspectives on Legitimacy and Legitimation, 57 AnN. REv. OF Psych. 375 (2006) (summarizing research and emphasizing procedural justice); James R. Kluegel \& David S. Mason, Fairness Matters: Social Justice and Political Legitimacy in Post-Communist Europe, 56 EUR.-Asia STUDIES 813, 826 (2004) ("[T] political support in these countries [based on prior studies] . . . B But it is clear from the results here
} 
probably only beginning to understand exactly how people conduct productive discussions that reconcile more than they aggravate, along with the circumstances under which people will agree to acquiesce despite opposition from the loudest voices of conscience. Something similar can be said about those who study the dynamic interaction of constitutional and nonconstitutional politics, and of legal and nonlegal institutions. Whatever the most persuasive answers to the issues surrounding fundamental societal disagreement, discourse theorists in general and constitutional discourse theorists in particular are unlikely to produce those answers on their own. Most likely, they will have to talk to others who are talking in a different language.

Readers with comments may address them to:

Professor Adam M. Samaha

University of Chicago Law School

1111 East 60th Street

Chicago, IL 60637

asamaha@uchicago.edu

\footnotetext{
that economic success alone will not necessarily guarantee popular support for the new governments.”); Mitchell A. Seligson, The Impact of Corruption on Regime Legitimacy, $64 \mathrm{~J}$. PoLIT. 408, 423-26, 430-31 (2002) (finding that reported experience with corruption is associated with the erosion of trust in four political regimes under study, albeit within a statistical model that explained relatively little of the variation in the data); $c f$. Wendy Nelson Espeland \& Mitchell L. Stevens, Commensuration as a Social Process, 24 AnN. Rev. Sociology 313, 330-31 (1998) (pointing out that, among other effects, the use of quantitative analysis can win legitimacy while diminishing the autonomy of elite decision makers).
} 


\section{The University of Chicago Law School Public Law and Legal Theory Working Paper Series}

For a listing of papers 1-345 please go to http://www.law.uchicago.edu/publications/papers/publiclaw.

346. Rosalind Dixon and Richard Holden, Constitutional Amendment Rules: The Denominator Problem, May 2011

347. Rosalind Dixon, Constitutional Amendment Rules: A Comparative Perspective, May 2011

348. Rosalind Dixon, Weak-Form Judicial Review and American Exceptionalism, May 2011

349. Rosalind Dixon, Transnational Constitutionalism and Unconstitutional Constitutional Amendments, May 2011

350. Adam B. Cox and Richard T. Holden, Reconsidering Racial and Partisan Gerrymandering, May 2011

351. Brian Leiter, The Circumstances of Civility, May 2011

352. Brian Leiter, Naturalized Jurisprucence and American Legal Realism Revisited, May 2011

353. Lee Anne Fennell, Property and Precaution, June 2011

354. Alon Harel and Ariel Porat, Commensurability and Agency: Two Yet-to-Be-Met Challenges for Law and Economics, June 2011

355. Bernard E. Harcourt, Radical Throught from Marx, Nietzsche, and Freud, through Foucault, to the Present: Comments on Steven Lukes' "In Defense of False Consciousness,” June 2011

356. Alison L. LaCroix, Rhetoric and Reality in Early American Legal History: A Reply to Gordon Wood, July 2011

357. Martha C. Nussbaum, Teaching Patriotism: Love and Critical Reform, July 2011

358. Shai Dothan, Judicial Tactics in the European Court of Human Rights, August 2011

359. Jonathan S. Masur and Eric A. Posner, Regulation, Unemployment, and Cost-Benefit Analysis, August, 2011

360. Adam B. Cox and Eric A. Posner, Delegation in Immigration Law, September 2011

361. José Antonio Cheibub, Zahcary Elkins, and Tom Ginsburg, Latin American Presidentialism in Comparative and Historical Perspective, September 2011

362. Tom Ginsburg and Rosalind Dixon, Comparative Constitutional Law: Introduction, September 2011

363. Eric A. Posner, Deference to the Executive in the United States after 9/11: Congress, the Courts, and the Office of Legal Counsel, September 2011

364. Adam M. Samaha, Regulation for the Sake of Appearance, October 2011

365. Ward Farnsworth, Dustin Guzior and Anup Malani, Implicit Bias in Legal Interpretation, October 2011

366. Scott A. Baker and Anup Malani, Does Accuracy Improve the Information Value of Trials? October 2011

367. Anup Malani, Oliver Bembom, and Mark van der Laan, Improving the FDA Approval Process, October 2011

368. Adam M. Samaha, Talk about Talking about Constitutional Law, October 2011 